\title{
Nitratireductor aquimarinus sp. nov., isolated from a culture of the diatom Skeletonema costatum, and emended description of the genus Nitratireductor
}

\author{
Gwang II Jang, Chung Yeon Hwang and Byung Cheol Cho
}

Correspondence

Byung Cheol Cho

bccho@snu.ac.kr
School of Earth and Environmental Sciences and Research Institute of Oceanography, Seoul National University, 599 Gwanak-ro, Gwanak-gu, Seoul 151-742, Republic of Korea

Two Gram-negative-staining, aerobic bacterial strains, designated CL-SC21 ${ }^{\top}$ and CL-SC22, were isolated from a culture of the diatom Skeletonema costatum (Korean Marine Microalgae Culture Center, KMMCC strain B-396) established from the East Sea, Korea. The two novel strains shared $99.9 \% 16 \mathrm{~S}$ rRNA gene sequence similarity. Analysis of the $16 \mathrm{~S}$ rRNA gene sequences showed an affiliation with the genus Nitratireductor, with the strains sharing 96.5$97.5 \%$ similarity with the type strains of recognized species of the genus Nitratireductor and being most closely related to Nitratireductor aquibiodomus $\mathrm{NL}^{2} 1^{\top}$. Phylogenetic analyses of the $16 \mathrm{~S}$ rRNA gene sequences showed that strain CL-SC21 ${ }^{\top}$ together with strain CL-SC22 belonged to the genus Nitratireductor and formed a robust clade among closely related Nitratireductor species. The polar lipids comprised phosphatidylcholine, phosphatidylglycerol, diphosphatidylglycerol, phosphatidylethanolamine, phosphatidylmonomethylethanolamine, two unidentified aminophospholipids, an unidentified aminolipid, an unidentified phospholipid and five unidentified lipids. Ubiquinone 10 was the major quinone. The major cellular fatty acids of strains CL-SC2 $1^{\top}$ and CL-SC22 were $\mathrm{C}_{18: 1} \omega 7 c(70.6-72.3 \%)$ and $\mathrm{C}_{19: 0} \omega 8 c$ cyclo $(10.9-11.8 \%)$. The genomic DNA G $+\mathrm{C}$ contents of strains CL-SC21 ${ }^{\top}$ and CL-SC22 were 56.7 and $57.1 \mathrm{~mol} \%$, respectively. The level of DNA-DNA relatedness between strains CL-SC2 $1^{\top}$ and CL-SC22 was $86 \%$ (reciprocal $91 \%$ ), indicating that the two isolates represented a single species. However, levels of DNA-DNA relatedness between $N$. aquibiodomus $\mathrm{NL}^{\top} 1^{\top}$ and strains CL-SC2 $1^{\top}$ and CL-SC22 were $28 \%$ (reciprocal $45 \%$ ) and $25 \%$ (reciprocal $50 \%$ ), respectively. Phylogenetic analysis and the results of biochemical tests showed that strains $\mathrm{CL}-\mathrm{SC} 21^{\top}$ and CL-SC22 were different from all recognized species of the genus Nitratireductor. Thus, strains $\mathrm{CL}-\mathrm{SC} 21^{\top}$ and $\mathrm{CL}-\mathrm{SC} 22$ represent a novel species of the genus Nitratireductor, for which the name Nitratireductor aquimarinus sp. nov. is proposed. The type strain is $\mathrm{CL}-\mathrm{SC} 21^{\top}(=\mathrm{KCCM}$ $90090^{\top}=$ JCM $17288^{\top}$ ).
The genus Nitratireductor, a member of the family Phyllobacteriaceae, was formally described by Labbé et al. (2004) and, at the time of writing, comprised five recognized species, Nitratireductor aquibiodomus, $N$. basaltis, N. kimnyeongensis, N. indicus and N. pacificus. N. aquibiodomus $\mathrm{NL}^{2} 1^{\mathrm{T}}$, a nitratereducing bacterium, was isolated from a marine denitrification system of the Montreal Biodome (Labbé et al., 2004). N. basaltis was isolated from black beach sand of Jeju Island, Korea (Kim et al., 2009). N. kimnyeongensis (Kang et al., 2009) was isolated from a dried seaweed sample collected from Kimnyeong Beach in Jeju, Korea. N. indicus (Lai et al., 2011b)

The GenBank/EMBL/DDBJ accession numbers for the 16S rRNA gene sequences of strains CL-SC2 $1^{\top}$ and CL-SC22 are HQ176467 and HO176466, respectively.

One supplementary figure and a supplementary table are available with the online version of this paper. and N. pacificus (Lai et al., 2011a) were isolated from deep-sea water of the Indian Ocean and deep-sea sediment of the Pacific Ocean, respectively. The aim of the present study was to determine the taxonomic positions of two Nitratireductorlike strains, CL-SC $21^{\mathrm{T}}$ and CL-SC22, isolated from a diatom culture.

A culture of the diatom Skeletonema costatum (KMMCC strain B-396) has been established from the east coast of Korea and maintained by transferring small quantities of culture to $\mathrm{f} / 2$ medium (Guillard \& Ryther, 1962). For isolating bacteria from the diatom culture, an aliquot $(10 \mu \mathrm{l})$ of the culture in the exponential phase was taken and spread on marine agar 2216 (MA; Difco) plates and incubated aerobically at $30{ }^{\circ} \mathrm{C}$ for 1 week. Two novel strains, $\mathrm{CL}-\mathrm{SC} 21^{\mathrm{T}}$ and CL-SC22, were isolated and subsequently streaked onto fresh MA at $30{ }^{\circ} \mathrm{C}$. The purification procedure 
was repeated four times. The two novel strains were able to grow well on trypticase soy agar (TSA; Difco) at $35{ }^{\circ} \mathrm{C}$. The two strains were maintained on TSA at $35{ }^{\circ} \mathrm{C}$ and preserved in trypticase soy broth (TSB; Difco) supplemented with $30 \%(\mathrm{v} / \mathrm{v})$ glycerol at $-80{ }^{\circ} \mathrm{C}$.

Morphological and physiological analyses were performed as follows. Unless otherwise specified, all characteristics of strains CL-SC2 $1^{\mathrm{T}}$ and CL-SC22 were based on cultures grown on TSA at $35{ }^{\circ} \mathrm{C}$. Gram-staining was performed as described by Smibert \& Krieg (1994). Motility of the cells was observed by the hanging-drop method (Suzuki et al., 2001). Cell morphology and presence of flagella were examined by transmission electron microscopy (EX2; JEOL). The temperature range for growth was determined on the basis of colony formation on TSA incubated at 5$45{ }^{\circ} \mathrm{C}$ (increments of $5{ }^{\circ} \mathrm{C}$ ) and $4{ }^{\circ} \mathrm{C}$. Growth at $\mathrm{pH} 5.1,5.6$, 6.0, 6.5, 6.9, 7.3, 7.7, 8.2, 8.6, 9.0, 9.3 and 9.6 was determined by assessing changes in $\mathrm{OD}_{600}$ over the incubation period (up to 10 days) in TSB at $35^{\circ} \mathrm{C}$; prior to autoclaving, $\mathrm{pH}$ (510 , at increments of $0.5 \mathrm{pH}$ units) was adjusted by using $1 \mathrm{M}$ $\mathrm{NaOH}$ and $1 \mathrm{M} \mathrm{HCl}$ solutions. After autoclaving and cooling, the $\mathrm{pH}$ values were measured for the subsamples of each medium, before inoculation of cells. The tolerance of strains CL-SC2 $1^{\mathrm{T}}$ and CL-SC22 to $\mathrm{NaCl}$ was determined on the basis of colony formation on synthetic ZoBell agar (per litre distilled water: $5 \mathrm{~g}$ Bacto peptone, $1 \mathrm{~g}$ yeast extract, $0.1 \mathrm{~g}$ ferric citrate, $15 \mathrm{~g}$ Bacto agar) supplemented with 0 $10 \%$ (increments of $1 \%$ ) and $15 \%(\mathrm{w} / \mathrm{v}) \mathrm{NaCl}$. Anaerobic growth was tested on TSA medium by using the GasPak anaerobic system (BBL) for 15 days. Resistance to antibiotics was determined by the disc diffusion plate method (Bauer et al., 1966) by using custom-made antibioticimpregnated discs.

For 16S rRNA gene amplification by PCR, DNA was extracted from a single colony by the boiling method (Englen \& Kelley, 2000). The crude extracts served as the DNA template for PCR, which included Taq DNA polymerase (Bioneer) and primers $27 \mathrm{~F}$ and 1492R (Lane, 1991). The PCR product was purified by using the AccuPrep PCR purification kit (Bioneer). Sequencing of the purified $16 \mathrm{~S}$ rRNA gene was performed by using sequencing primers (27F, 518F, 800R, 1492R; Lane, 1991; Anzai et al., 1997) with an Applied Biosystems automated sequencer (ABI3730XL) at Macrogen, Seoul, Korea. The almost-complete 16S rRNA gene sequences of strains CL-SC2 $1^{\mathrm{T}}$ (1417 bp) and CL-SC22 (1416 bp) were obtained and compared with available 16S rRNA gene sequences in the GenBank database by using BLASTN searches (Altschul et al., 1990). The sequences of strains CL-SC2 $1^{\mathrm{T}}$ and CL-SC22 were manually aligned via the jPHYDIT program (Jeon et al., 2005) with all available $16 S$ rRNA gene sequences from the type strains of recognized species of the genus Nitratireductor and with those of the type species of other genera in the family Phyllobacteriaceae, obtained from the GenBank and Ribosomal Database Project II databases (Cole et al., 2007). Accurate multiple alignment was made manually according to the $16 \mathrm{~S}$ rRNA gene secondary-structure information implemented in the
jPHYDIT program. Phylogenetic trees were constructed with the neighbour-joining (Saitou \& Nei, 1987), maximum-parsimony (Fitch, 1971) and maximum-likelihood (Felsenstein, 1981) methods. An evolutionary distance matrix for the neighbour-joining method was generated according to the model of Jukes \& Cantor (1969). The robustness of tree topologies was assessed by bootstrap analyses based on 1000 replications for the neighbour-joining and maximumparsimony methods. Phylogenetic analyses were carried out by using MEGA 4 (Tamura et al., 2007) and PAUP 4.0 (Swofford, 1998). Likelihood parameters were estimated by using hierarchical ratio tests in MODELTEST, version 3.04 (Posada \& Crandall, 1998). Levels of genomic DNA-DNA relatedness were determined by dot-blot hybridization (Kim et al., 2007). Pre-hybridization, hybridization $\left(45^{\circ} \mathrm{C}\right)$ and detection were performed by using a DIG labelling and detection kit (Roche Molecular Biochemicals) according to the manufacturer's instructions. The experiment was repeated on different days.

Polar lipids were extracted according to the procedures described by Minnikin et al. (1984) and were identified by two-dimensional TLC followed by spraying with appropriate detection reagents (Komagata \& Suzuki, 1987). The quinone system was determined according to Minnikin et al. (1984) and components were analysed by HPLC as described by Collins (1985) by using Cohaesibacter gelatinilyticus CL-GR15 ${ }^{\mathrm{T}}$ (Hwang \& Cho, 2008) as a reference strain. Cellular fatty acids of strains CL-SC2 $1^{\mathrm{T}}$ and CL-SC22 were extracted and derivatized to their fatty acid methyl esters according to the protocol of Miller (1982). The samples were then prepared according to the instructions of the Sherlock Microbial Identification System (MIDI; version 3.10) and were analysed by GC at the Korean Culture Center of Microorganisms (Seoul, Korea). The strains were grown on TSA (Difco) at $35{ }^{\circ} \mathrm{C}$ for 3 days and on MA at $28{ }^{\circ} \mathrm{C}$ for 2 days. The DNA G $+\mathrm{C}$ content was analysed by HPLC (HP 100; Hewlett Packard) of deoxyribonucleosides as described by Mesbah et al. (1989), after DNA extraction according to Marmur (1961). N. aquibiodomus $\mathrm{NL}_{2}{ }^{\mathrm{T}}$ was used as a standard.

In the following biochemical tests, N. aquibiodomus $\mathrm{NL} 21^{\mathrm{T}}$ was used as a reference strain. Catalase and oxidase were assayed according to the protocols described by Smibert \& Krieg (1994). Strains were tested for the ability to reduce nitrate under anaerobic conditions at $35{ }^{\circ} \mathrm{C}$ in TSB supplemented with $10 \mathrm{mM} \mathrm{NO}-$ as $\mathrm{KNO}_{3}$ and $10 \mu \mathrm{M}$ phenol red (Vanparys et al., 2005). The presence of nitrite and nitrate was tested after 2 and 5 days by using the procedure described by Smibert \& Krieg (1994). The biochemical characteristics of strains CL-SC21 ${ }^{\mathrm{T}}, \mathrm{CL}-\mathrm{SC} 22, N$. aquibiodomus $\mathrm{NL} 21^{\mathrm{T}}, N$. basaltis $\mathrm{J}^{\mathrm{T}}$ and $N$. kimnyeongensis $\mathrm{KY} 101^{\mathrm{T}}$ were determined by using the API ZYM and API 20NE kits (bioMérieux) according to the manufacturer's instructions, except that the cell suspension was prepared with artificial seawater (per litre distilled water: $24 \mathrm{~g} \mathrm{NaCl}, 10.9 \mathrm{~g} \mathrm{MgCl}_{2} .6 \mathrm{H}_{2} \mathrm{O}, 4 \mathrm{~g} \mathrm{Na}_{2} \mathrm{SO}_{4}$, $1.5 \mathrm{~g} \mathrm{CaCl}_{2} .2 \mathrm{H}_{2} \mathrm{O}, 0.7 \mathrm{~g} \mathrm{KCl}, 0.2 \mathrm{~g} \mathrm{NaHCO}_{3}, 0.1 \mathrm{~g} \mathrm{KBr}$, $0.027 \mathrm{~g} \mathrm{H}_{3} \mathrm{BO}_{3}, 0.03 \mathrm{~g} \mathrm{SrCl}_{2} .6 \mathrm{H}_{2} \mathrm{O}, 0.003 \mathrm{~g} \mathrm{NaF}$; Lyman \& 
Fleming, 1940). For tests with the API ZYM and API 20NE kits, all strains were cultivated on MA at $35^{\circ} \mathrm{C}$ for 2 days.

The level of 16S rRNA gene sequence similarity between strains CL-SC2 $1^{\mathrm{T}}$ and CL-SC22 was $99.9 \%$. Analysis of $16 \mathrm{~S}$ rRNA gene sequences showed an affiliation with the genus Nitratireductor, the two novel strains sharing 96.5-97.5\% similarity with the type strains of recognized species of the genus Nitratireductor and being most closely related to N. aquibiodomus $\mathrm{NL} 21^{\mathrm{T}}$. Phylogenetic analyses of the $16 \mathrm{~S}$ rRNA gene sequences showed that strain CL-SC21 ${ }^{\mathrm{T}}$ formed a robust clade with strain CL-SC22, and that this clade clustered tightly with the nearest clade containing $N$. aquibiodomus $\mathrm{NL} 21^{\mathrm{T}}$ and N. kimnyeongensis $\mathrm{KY} 101^{\mathrm{T}}$ (Fig. 1). Thus, the distinct phylogenetic position of the two strains indicated that they represented a novel species of the genus Nitratireductor. The mean level of DNA-DNA relatedness between strains CL-SC $21^{\mathrm{T}}$ and CL-SC22 was $86 \pm 1 \%$ (reciprocal $91 \pm 1 \%$ ), indicating that these two strains belonged to a single species. Mean levels of DNADNA relatedness between $N$. aquibiodomus $\mathrm{NL}_{2} 1^{\mathrm{T}}$ and strains CL-SC2 $1^{\mathrm{T}}$ and CL-SC22 were $28 \pm 16 \%$ (reciprocal $45 \pm 18 \%$ ) and $25 \pm 8 \%$ (reciprocal $50 \pm 1 \%$ ), respectively. These values are below the currently accepted cut-off $(70 \%)$ for the phylogenetic definition of a species (Stackebrandt \& Goebel, 1994) and therefore the phylogenetic and genomic

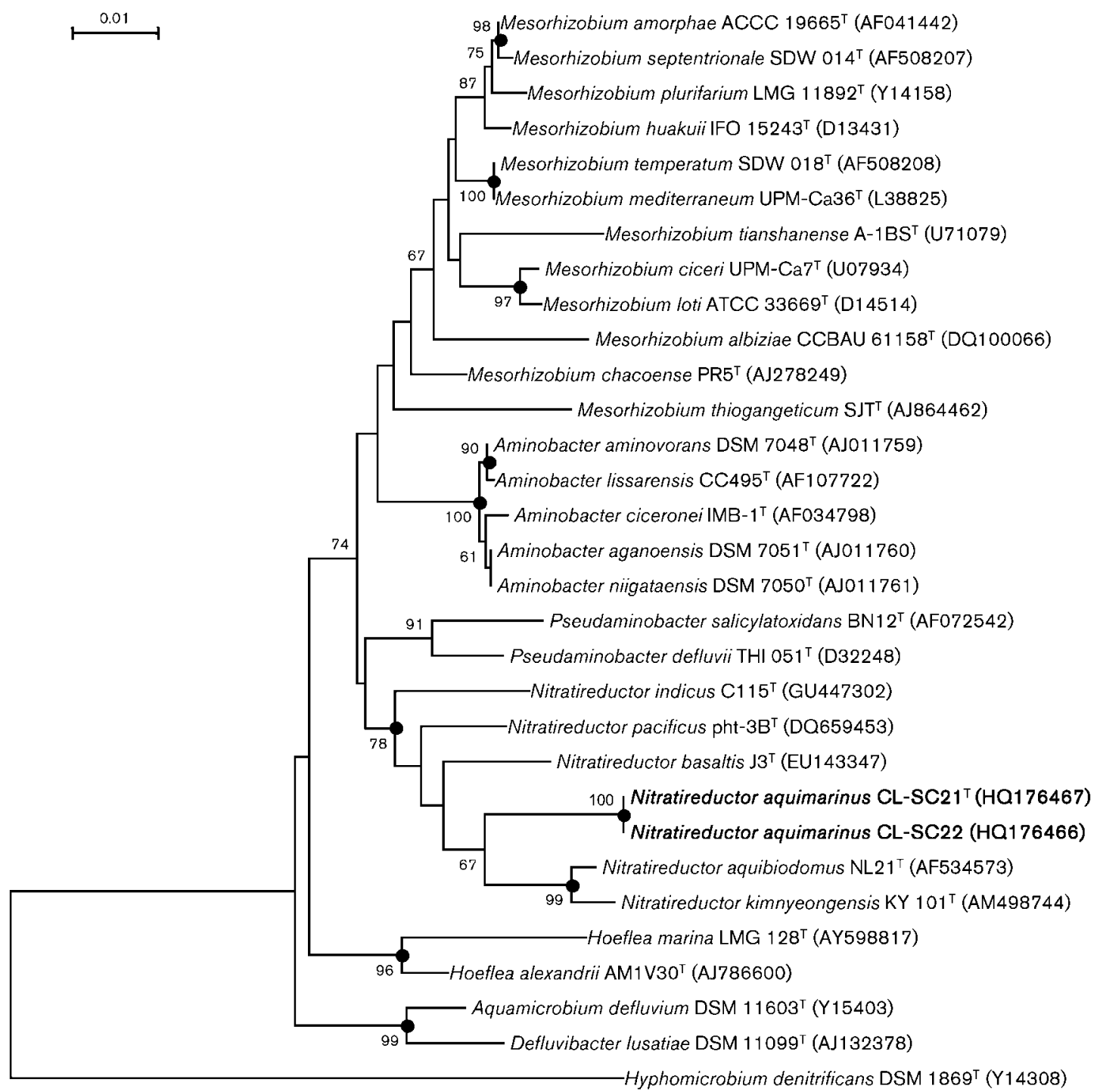

Fig. 1. Neighbour-joining tree based on $16 \mathrm{~S}$ rRNA gene sequences showing the phylogenetic positions of strains $C L-S C 21^{\top}$ and CL-SC22, and the type strains of recognized species of the genus Nitratireductor and members of the family Phyllobacteriaceae; Hyphomicrobium denitrificans DSM $1869^{\top}$ was used as the outgroup. Bootstrap values (percentages of 1000 resamplings) are shown at branch points; only values $>60 \%$ are shown. Solid circles indicate that the corresponding nodes were also obtained in the maximum-likelihood and maximum-parsimony trees. Bar, $0.01 \mathrm{nt}$ substitutions per site. 
evidence indicates that strains CL-SC2 $1^{\mathrm{T}}$ and CL-SC22 represent a single novel species of the genus Nitratireductor.

The major polar lipids of strain CL-SC2 $1^{\mathrm{T}}$ were phosphatidylcholine, phosphatidylglycerol, diphosphatidylglycerol, phosphatidylethanolamine, phosphatidylmonomethylethanolamine, two unidentified aminophospholipids, an unidentified aminolipid and three unidentified lipids (see Supplementary Fig. S1 in IJSEM Online). An unidentified phospholipid and two unidentified lipids were detected in minor amounts (Supplementary Fig. S1). All the above polar lipids were commonly detected in strain CL-SC $21^{\mathrm{T}}$ and in $N$. aquibiodomus $\mathrm{NL}_{2}{ }^{\mathrm{T}}$ (Supplementary Fig. S1). The major quinone was ubiquinone $10(\mathrm{Q}-10)$ for strains CL-SC21 ${ }^{\mathrm{T}}$, CL-SC22 and $N$. aquibiodomus $\mathrm{NL} 21^{\mathrm{T}}$. The fatty acid profiles of strains CL-SC21 ${ }^{\mathrm{T}}$ and CL-SC22 were similar (Supplementary Table S1): the major components were $\mathrm{C}_{18: 1} \omega 7 c(70.6-72.3 \%)$ and $\mathrm{C}_{19: 0} \omega 8 c$ cyclo $(10.9-11.8 \%)$. These fatty acids are also found as major components in related species of the genus Nitratireductor (Supplementary Table S1). The genomic DNA G $+\mathrm{C}$ contents of strains CL-SC21 ${ }^{\mathrm{T}}$ and CL-SC22 (56.7 and $57.1 \mathrm{~mol} \%$, respectively) were within the range reported for members of the genus Nitratireductor, but differed distinctly from that of the type strain of N. pacificus (63 mol\%; Lai et al., 2011a). Strains CL-SC $21^{\mathrm{T}}$ and CL-SC22 had traits differentiating them from

Table 1. Differential characteristics between strains CL-SC21 $1^{\top}$ and CL-SC22 and the type strains of recognized species of the genus Nitratireductor

Strains: 1, CL-SC21 ${ }^{\mathrm{T}}$ and CL-SC22; 2, N. aquibiodomus NL21 ${ }^{\mathrm{T}}$ (unless indicated otherwise, data from Labbé et al., 2004); 3, N. basaltis J3 ${ }^{\mathrm{T}}$ (Kim et al., 2009); 4, N. kimnyenogensis KY $101^{\mathrm{T}}$ (Kang et al., 2009). +, Positive; -, negative; w, weakly positive. All strains are Gram-negative-staining and oxidase- and catalase-positive. In API ZYM and API 20NE tests, all strains are positive or weakly positive for alkaline phosphatase, acid phosphatase, esterase (C4), esterase lipase (C8), leucine arylamidase, naphthol-AS-BI-phosphohydrolase, trypsin and valine arylamidase, but negative for lipase (C14), $\alpha$-chymotrypsin, $\alpha$-fucosidase, $\beta$-glucuronidase, $\beta$-glucosidase, $\alpha$-mannosidase and gelatinase, indole production, glucose fermentation and assimilation of caprate and phenylacetate.

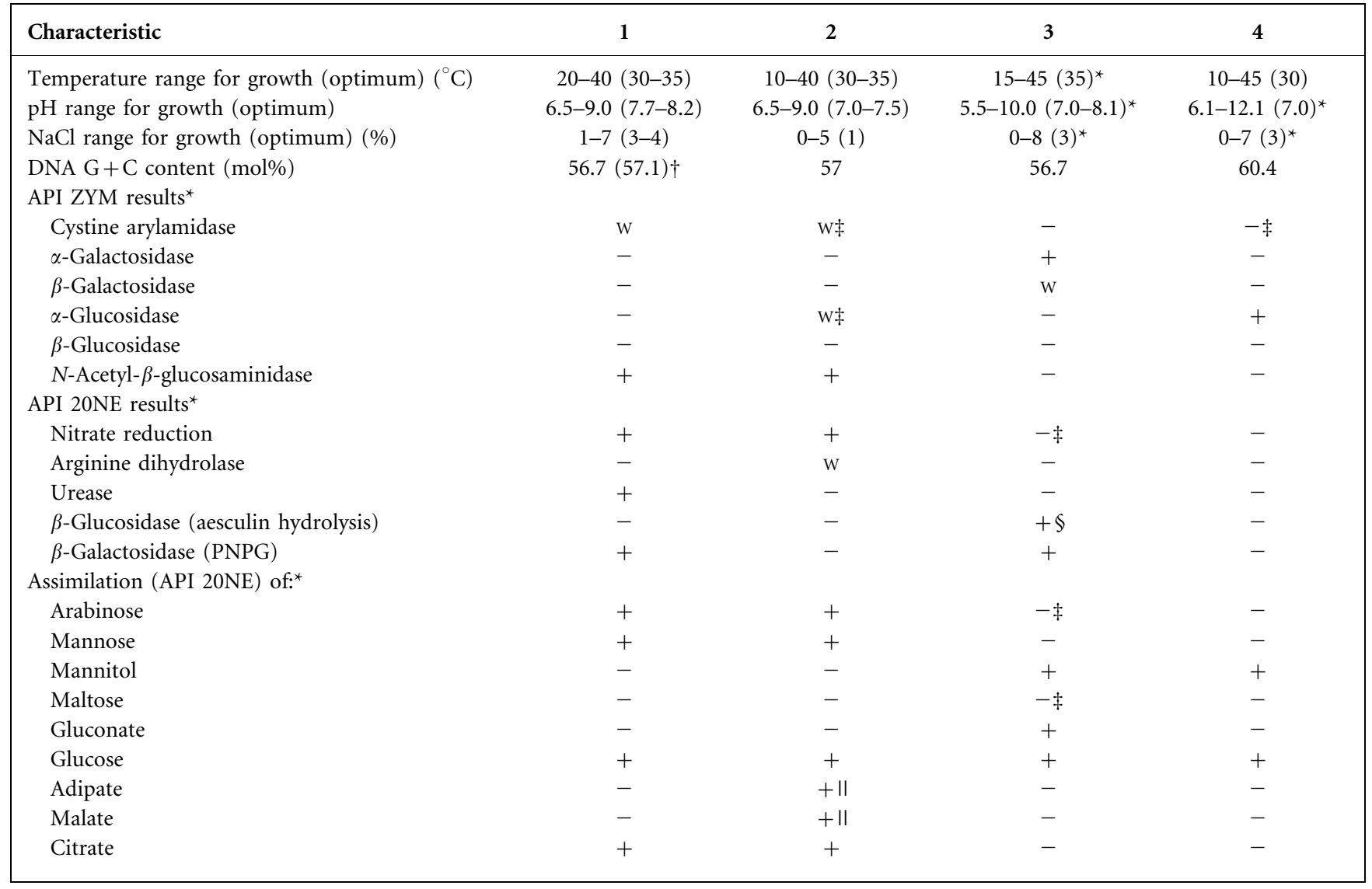

${ }^{\star}$ Data from this study.

$\dagger$ Data in parentheses are for strain CL-SC22.

$\$$ Positive in each original study.

$\S$ Negative in Kim et al. (2009).

IIWeakly positive in Labbé et al. (2004). 
recognized species of the genus Nitratireductor. For example, the minimum temperature for growth of strains CL-SC2 $1^{\mathrm{T}}$ and CL-SC22 $\left(20^{\circ} \mathrm{C}\right)$ was higher than those of $N$. aquibiodomus, $N$. basaltis and $N$. kimnyenogensis (10$15{ }^{\circ} \mathrm{C}$, Table 1). Strains CL-SC2 $1^{\mathrm{T}}$ and CL-SC22 could be distinguished from $N$. aquibiodomus, $N$. basaltis and $N$. kimnyenogensis based on the presence of urease activity (Table 1). Strains CL-SC $21^{\mathrm{T}}$ and CL-SC22 differed from their closest phylogenetic neighbour, $N$. aquibiodomus, based on inability to grow without $\mathrm{NaCl}$, the absence of arginine dihydrolase and $\alpha$-glucosidase activities, and the presence of $\beta$-galactosidase (API 20NE) activity (Table 1). Strains CL-SC $21^{\mathrm{T}}$ and CL-SC22 could be distinguished from $N$. basaltis and $N$. kimnyeongensis by their inability to grow without $\mathrm{NaCl}$ and the presence of $N$-acetyl- $\beta$-glucosaminidase activity (Table 1). They could be distinguished from $N$. pacificus and $N$. indicus by their inability to grow without $\mathrm{NaCl}$, and inability to grow at $\mathrm{pH} 5$ and at $10-15{ }^{\circ} \mathrm{C}$ under the same conditions as described in Lai et al. (2011a, b) (data not shown). Thus, on the basis of the data from the present polyphasic study, strains CL-SC21 ${ }^{\mathrm{T}}$ and CL-SC22 are considered to represent a single novel species of the genus Nitratireductor, for which the name Nitratireductor aquimarinus sp. nov. is proposed.

\section{Emended description of the genus Nitratireductor Labbé et al. 2004}

With the properties given in the descriptions of species of the genus Nitratireductor in earlier studies (Kang et al., 2009; Kim et al., 2009; Lai et al., 2011a, b) and the present study, the description of the genus given by Labbé et al. (2004) is emended as follows. Cells are rods, short rods or coccoid. Motility is variable. Colony colour is white, light yellow, smooth grey or cream. Optimum temperature for growth is $25-35{ }^{\circ} \mathrm{C}$. Growth occurs at $\mathrm{pH} 5-12$. Nitrate reduction is variable. Major polar lipids are phosphatidylcholine, phosphatidylglycerol, diphosphatidylglycerol, phosphatidylethanolamine, phosphatidylmonomethylethanolamine, two unidentified aminophospholipids and three unidentified lipids. Major quinone is Q- 10 . DNA G + C content is $56.7-63 \mathrm{~mol} \%$.

\section{Description of Nitratireductor aquimarinus sp. nov.}

Nitratireductor aquimarinus (a.qui.ma.ri'nus. L. fem. n. aqua water; L. adj. marinus-, $-a$, - - um marine, of the sea; N.L. masc. adj. aquimarinus pertaining to seawater).

Cells are rod-shaped, approximately $0.4-0.7 \mu \mathrm{m}$ wide and 1.3-2.0 $\mu \mathrm{m}$ long. Cells are Gram-negative-staining, strictly aerobic and motile by means of a polar flagellum. After 3 days on TSA and MA plates at $35{ }^{\circ} \mathrm{C}$, colonies are smooth, circular, convex and creamy in colour. Growth occurs at $20-40{ }^{\circ} \mathrm{C}$ (optimum $30-35{ }^{\circ} \mathrm{C}$ ), at $\mathrm{pH} 6.5-9.0$ (optimum $\mathrm{pH}$ 7.7-8.2) and in the presence of $1-7 \%(\mathrm{w} / \mathrm{v})$ $\mathrm{NaCl}$ (optimum $3-4 \% \mathrm{NaCl}$ ). Positive for oxidase and catalase. Nitrate is reduced. According to API ZYM tests, positive for acid phosphatase, alkaline phosphatase, cystine arylamidase (weak), esterase (C4), esterase lipase (C8; weak for strain CL-SC22), leucine arylamidase, naphthol-AS-BIphosphohydrolase, trypsin, valine arylamidase (weak) and $N$-acetyl- $\beta$-glucosaminidase activities, but negative for $\alpha$ chymotrypsin, $\alpha$-fucosidase, $\alpha$-galactosidase, $\beta$-galactosidase, $\alpha$-glucosidase, $\beta$-glucosidase, $\beta$-glucuronidase, lipase (C14) and $\alpha$-mannosidase activities. According to API $20 \mathrm{NE}$ tests, positive for nitrate reduction, $\beta$-galactosidase, urease, and assimilation of arabinose, $\mathrm{N}$-acetylglucosamine, citrate, glucose and mannose, but negative for arginine dihydrolase, aesculin hydrolysis, gelatinase, glucose fermentation, indole production, and assimilation of adipate, caprate, gluconate, malate, maltose, mannitol and phenylacetate. Cells are sensitive to ( $\mu \mathrm{g}$ per disc) ampicillin (6), chloramphenicol (20), cephalexin (20), erythromycin (10), gentamicin (6), kanamycin (20), polymyxin B (25), streptomycin (6), tetracycline (20) and vancomycin (20), but resistant to nalidixic acid (20), mitomycin $\mathrm{C}(0.6)$ and penicillin $\mathrm{G}(6)$. The major cellular fatty acids are $\mathrm{C}_{18: 1} \omega 7 c$ and $\mathrm{C}_{19: 0} \omega 8 c$ cyclo. The DNA G+C content is $56.7-$ $57.1 \mathrm{~mol} \%$.

The type strain, CL-SC $21^{\mathrm{T}}\left(=\mathrm{KCCM} 90090^{\mathrm{T}}=\mathrm{JCM} 17288^{\mathrm{T}}\right)$, was isolated from a culture of the diatom Skeletonema costatum. CL-SC22, isolated from the same source, is a second strain of the species.

\section{Acknowledgements}

We acknowledge the expert technical support of Ms In-Sung Lee (electron microscopy) of the National Center for Inter-university Research Facilities at Seoul National University. This work was supported in part by the BK21 project of the Korean Government, by the MarineBio Technology Program funded by the Ministry of Land, Transport, and Maritime Affairs (MLTM), Korea, and by the Ministry of Maritime Affairs and Fisheries (the Korea EAST-1 program).

\section{References}

Altschul, S. F., Gish, W., Miller, W., Myers, E. W. \& Lipman, D. J. (1990). Basic local alignment search tool. J Mol Biol 215, 403-410.

Anzai, Y., Kudo, Y. \& Oyaizu, H. (1997). The phylogeny of the genera Chryseomonas, Flavimonas, and Pseudomonas supports synonymy of these three genera. Int J Syst Bacteriol 47, 249-251.

Bauer, A. W., Kirby, W. M. M., Sherris, J. C. \& Turck, M. (1966). Antibiotic susceptibility testing by a standardized single disk method. Am J Clin Pathol 45, 493-496.

Cole, J. R., Chai, B., Farris, R. J., Wang, Q., Kulam-Syed-Mohideen, A. S., McGarrell, D. M., Bandela, A. M., Cardenas, E., Garrity, G. M. \& Tiedje, J. M. (2007). The ribosomal database project (RDP-II): introducing $m y R D P$ space and quality controlled public data. Nucleic Acids Res 35 (Database issue), D169-D172.

Collins, M. D. (1985). Isoprenoid quinone analysis in classification and identification. In Chemical Methods in Bacterial Systematics, pp. 267-287. Edited by M. Goodfellow \& D. E. Minnikin. London: Academic Press.

Englen, M. D. \& Kelley, L. C. (2000). A rapid DNA isolation procedure for the identification of Campylobacter jejuni by the polymerase chain reaction. Lett Appl Microbiol 31, 421-426. 
Felsenstein, J. (1981). Evolutionary trees from DNA sequences: a maximum likelihood approach. J Mol Evol 17, 368-376.

Fitch, W. M. (1971). Toward defining the course of evolution: minimum change for a specific tree topology. Syst Zool 20, 406-416.

Guillard, R. R. L. \& Ryther, J. H. (1962). Studies of marine planktonic diatoms. I. Cyclotella nana Hustedt, and Detonula confervacea (cleve) Gran. Can J Microbiol 8, 229-239.

Hwang, C. Y. \& Cho, B. C. (2008). Cohaesibacter gelatinilyticus gen. nov., sp. nov., a marine bacterium that forms a distinct branch in the order Rhizobiales, and proposal of Cohaesibacteraceae fam. nov. Int $J$ Syst Evol Microbiol 58, 267-277.

Jeon, Y. S., Chung, H., Park, S., Hur, I., Lee, J. H. \& Chun, J. (2005). jPHYDIT: a JAVA-based integrated environment for molecular phylogeny of ribosomal RNA sequences. Bioinformatics 21, 3171-3173.

Jukes, T. H. \& Cantor, C. R. (1969). Evolution of protein molecules. In Mammalian Protein Metabolism, vol. 3, pp. 21-132. Edited by H. N. Munro. New York: Academic Press.

Kang, H. S., Yang, H. L. \& Lee, S. D. (2009). Nitratireductor kimnyeongensis sp. nov., isolated from seaweed. Int J Syst Evol Microbiol 59, 1036-1039.

Kim, Y.-G., Choi, D. H., Hyun, S. \& Cho, B. C. (2007). Oceanobacillus profundus sp. nov., isolated from a deep-sea sediment core. Int J Syst Evol Microbiol 57, 409-413.

Kim, K. H., Roh, S. W., Chang, H. W., Nam, Y. D., Yoon, J. H., Jeon, C. O., Oh, H. M. \& Bae, J. W. (2009). Nitratireductor basaltis sp. nov., isolated from black beach sand. Int J Syst Evol Microbiol 59, 135-138.

Komagata, K. \& Suzuki, K. (1987). Lipids and cell-wall analysis in bacterial systematics. Methods Microbiol 19, 161-207.

Labbé, N., Parent, S. \& Villemur, R. (2004). Nitratireductor aquibiodomus gen. nov., sp. nov., a novel alpha-proteobacterium from the marine denitrification system of the Montreal Biodome (Canada). Int J Syst Evol Microbiol 54, 269-273.

Lai, Q., Yu, Z., Wang, J., Zhong, H., Sun, F., Wang, L., Wang, B. \& Shao, Z. (2011a). Nitratireductor pacificus sp. nov., isolated from a pyrene-degrading consortium. Int J Syst Evol Microbiol 61, 1386-1391.

Lai, Q., Yu, Z., Yuan, J., Sun, F. \& Shao, Z. (2011b). Nitratireductor indicus sp. nov., isolated from deep-sea water. Int J Syst Evol Microbiol 61, 295-298.

Lane, D. J. (1991). 16S/23S rRNA sequencing. In Nucleic Acid Techniques in Bacterial Systematics, pp. 115-175. Edited by E. Stackebrandt \& M. Goodfellow. Chichester: Wiley.
Lyman, J. \& Fleming, R. H. (1940). Composition of sea water. J Mar Res 3, 134-146.

Marmur, J. (1961). A procedure for the isolation of deoxyribonucleic acid from micro-organisms. J Mol Biol 3, 208-218.

Mesbah, M., Premachandran, U. \& Whitman, W. B. (1989). Precise measurement of the $\mathrm{G}+\mathrm{C}$ content of deoxyribonucleic acid by high performance liquid chromatography. Int J Syst Bacteriol 39, 159-167.

Miller, L. T. (1982). Single derivatization method for routine analysis of bacterial whole-cell fatty acid methyl esters, including hydroxy acids. J Clin Microbiol 16, 584-586.

Minnikin, D. E., O'Donnell, A. G., Goodfellow, M., Alderson, G., Athalye, M., Schaal, K. \& Parlett, J. H. (1984). An integrated procedure for the extraction of bacterial isoprenoid quinones and polar lipids. J Microbiol Methods 2, 233-241.

Posada, D. \& Crandall, K. A. (1998). MODELTEST: testing the model of DNA substitution. Bioinformatics 14, 817-818.

Saitou, N. \& Nei, M. (1987). The neighbor-joining method: a new method for reconstructing phylogenetic trees. Mol Biol Evol 4, 406425.

Smibert, R. M. \& Krieg, N. R. (1994). Phenotypic characterization. In Methods for General and Molecular Bacteriology, pp. 607-654. Edited by P. Gerhardt, R. G. E. Murray, W. A. Wood \& N. R. Krieg. Washington, DC: American Society for Microbiology.

Stackebrandt, E. \& Goebel, B. M. (1994). Taxonomic note: a place for DNA-DNA reassociation and $16 \mathrm{~S}$ rRNA sequence analysis in the present species definition in bacteriology. Int J Syst Bacteriol 44, 846849.

Suzuki, M., Nakagawa, Y., Harayama, S. \& Yamamoto, S. (2001). Phylogenetic analysis and taxonomic study of marine Cytophaga-like bacteria: proposal for Tenacibaculum gen. nov. with Tenacibaculum maritimum comb. nov. and Tenacibaculum ovolyticum comb. nov., and description of Tenacibaculum mesophilum sp. nov. and Tenacibaculum amylolyticum sp. nov. Int J Syst Evol Microbiol 51, 1639-1652.

Swofford, D. L. (1998). Phylogenetic analysis using parsimony (PAUP), version 4. Sunderland, MA: Sinauer Associates.

Tamura, K., Dudley, J., Nei, M. \& Kumar, S. (2007). MEGA4: molecular evolutionary genetics analysis (MEGA) software version 4.0. Mol Biol Evol 24, 1596-1599.

Vanparys, B., Heylen, K., Lebbe, L. \& De Vos, P. (2005). Devosia limi sp. nov., isolated from a nitrifying inoculum. Int J Syst Evol Microbiol 55, 1997-2000. 